\title{
Realizacja misji felicjanek w epoce Internetu
}

Ks. prof. zw. dr hab. WoJciech Misztal

Uniwersytet Papieski Jana Pawła II w Krakowie

Internet - chociaż może raczej należałoby tu użyć mniej znanego określenia web, pozostaniemy jednak przy rozpowszechnionym obecnie nazewnictwie - to w pewnym sensie: 1) symbol naszych czasów, 2) jeden z zasadniczych elementów wyróżniających lata, w których przyszło nam żyć, w odniesieniu do przeszłości, 3) to, co czyni współczesność większą, rozleglejszą, bardziej złożoną od minionych epok. Już w 2013 roku papież Benedykt XVI zwracał uwagę: „Świat cyfrowy nie jest światem paralelnym ani czysto wirtualnym, lecz dla wielu ludzi, zwłaszcza najmłodszych, stanowi część codziennej rzeczywistości” ${ }^{1}$. Jeśli druga dekada XXI wieku, „czasy Internetu”, czyli nasze „dzisiaj”, jest bardziej rozległa niż „wczoraj”, to wszystkim członkom Kościoła, także siostrom felicjankom, zadań nie ubyło, lecz przybyło. Ponownie warto przywołać nauczanie papieża Benedykta XVI i przytoczyć jego słowa: „Wyzwaniem, przed

${ }^{1}$ Benedykt XVI, messaggio per la XLVII Giornata Mondiale delle Comunicazioni Sociali Reti Sociali: porte di verità e di fede; nuovi spazi di evangelizzazione (24.01.2013), akapit 5, http://w2.vatican.va/content/ benedict-xvi/it/messages/communications/documents/hf_ben-xvi_ mes_20130124_47th-world-communications-day.html (1.03.2013). 
którym muszą stanąć sieci społecznościowe, jest to, aby były one rzeczywiście powszechne: wspomagać je będzie wówczas pełny udział wierzących, którzy pragną dzielić się orędziem Jezusa i wartościami godności ludzkiej, które krzewi Jego nauczanie. (...) jeśli Dobrej Nowiny nie będzie można poznać także w świecie cyfrowym, to może być ona nieobecna w doświadczeniu wielu osób, dla których ta przestrzeń egzystencjalna jest ważna"2.

By lepiej sobie uświadomić, z czym mamy do czynienia, można postawić następujące pytanie: jak człowiek żyjący w wielkim mieście w Europie w drugiej dekadzie XXI wieku odnalazłby się, przemieściwszy się w czasie do drugiej połowy wieku XIX? Kwestionariusz odpowiedzi na to pytanie mógłby zwracać uwagę np. na dostępność takich kwestii jak: bieżąca woda, ciepła woda, centralne ogrzewanie, kuchnia gazowa, elektryczna, pralka automatyczna, żelazko elektryczne z nawilżaczem, w którym gorące powietrze nie parzy trzymającej za rączkę żelazka dłoni (a tak było w przypadku żelazek rozgrzewanych „wkładem” z rozpalonego węgla drzewnego), zakupy w supermarketach, prąd elektryczny, oświetlenie elektryczne, m.in. umożliwiające czy ułatwiające modlitwę, naukę czy opiekę nad chorymi wieczorem i w nocy, komputer, drukarka, telefon komórkowy.

Zgromadzenie felicjanek pochodzi z innej epoki niż nasza współczesność, epoki bardzo od niej różnej. Powstało ono i zaczęło dynamicznie się rozwijać w drugiej połowie XIX wieku. Wtedy też wykrystalizowała się jego tożsamość,

2 Benedykt XVI, messaggio per la XLVII Giornata Mondiale delle Comunicazioni Sociali Reti Sociali: porte di verità e di fede; nuovi spazi di evangelizzazione (24.01.2013), akapit 5. 
charyzmat, misja: dokonało się to w odpowiedzi na potrzeby i możliwości, z których zdały sobie sprawę założycielka zgromadzenia, jej współpracownice i kontynuatorki, dbające o kontynuację i rozwój jej dzieła ${ }^{3}$. Mamy tu do czynienia z pewną sprawdzoną chrześcijańską zasadą, którą następująco ujął, odnosząc się do początków chrześcijaństwa, Raymond Edward Brown: „Naśladowanie mistrza jest wyrazem wdzięczności. Czerpać od niego natchnienie, by pójść dalej niż mistrz, to jeszcze większy wkład w pozostawione przez niego dziedzictwo. (...) To dziedzictwo jest nadal żywe, bo Paweł przygotował takie nowe pokolenie, które może działać tak skutecznie jak on sam"4.

Oto wybrane daty $\mathrm{z}$ historii zgromadzenia felicjanek: Zgromadzenie Sióstr św. Feliksa powstało 21 listopada 1855 roku. W roku 1860 miał miejsce, zgodnie z ówczesną praktyką, podział zgromadzenia na I chór - klauzurowy i II chór - oddający się działalności apostolskiej. W 1864 roku dokonano, decyzją władz zaborczych, w ramach represji za pomoc powstańcom styczniowym, kasaty zgromadzenia w zaborze rosyjskim. W 1882 roku powstał klasztor w Krakowie przy ulicy Smoleńsk. W 1899 roku nastąpiło kościelne zatwierdzenie zgromadzenia ${ }^{5}$. Fakty te prowadzą do postawienia pytania: jak zgromadzenie felicjanek odnajduje

${ }^{3}$ Zob. np. A. Górski, Angela Truszkowska i Zgromadzenie SS. Felicjanek na tle dziejów myśli religijnej w Polsce XIX w., przedmowa F. Machay, Poznań 1959, s. 21 i n.; J. Marecki, Błogosławiona Maria Angela Truszkowska, „Folia Historica Cracoviensia” 15/16 (2009/2010), s. 339 i n.

${ }^{4}$ R.E. Brown, Que sait-on du Nouveau Testament?, Paryż 2000, s. 497.

${ }^{5}$ Zob. np. Zgromadzenie Sióstr św. Feliksa z Kantalicjo - Prowincja Matki Bożej Królowej Polski w Warszawie, http://www.felicjanki.waw. pl/o-zgromadzeniu/historia (25.01.2018). 
się współcześnie, w bardzo przecież zmienionych okolicznościach, i co będzie w przyszłości? Czy przetrwa? Czy będzie dalej się rozwijać?

\section{Współczesność i jej cechy charakterystyczne}

Współczesność to rzeczywistość bardzo złożona i niezwykle obszerna. Realizując wskazany w tytule temat, należy przede wszystkim zwrócić uwagę na następujące związane z nią sprawy: kwestię roli religii współcześnie i przyszłości, w tym chrześcijaństwa i - bardziej szczegółowo - życia zakonnego ${ }^{6}$; kwestię zapewnienia pokoju, zagrożenia wojnami, konfliktami; procesy związane z globalizacją, a zarazem renesans poczucia przynależności i troski o „małe ojczyzny”. Niebagatelny nurt stanowią także: mentalność, przemyślenia i działania związane z relacjami ze środowiskiem naturalnym, z innymi bytami zamieszkującymi razem z ludźmi Ziemię, świadomość kryzysu ekologicznego i reagowanie na ten kryzys?.

Zmieniła się bardzo jakość sposobów przesyłania informacji i wzrosło ich natężenie, chociażby w związku z cy-

${ }^{6}$ Zob. np. J. Mariański, Sekularyzacja. Desekularyzacja. Nowa duchowość. Studium socjologiczne, Kraków 2013, s. 65 i n.

7 Portal warszawskiej prowincji felicjanek udostępnia informacje dotyczące działalności felicjańskiej Komisji Sprawiedliwości, Pokoju i Ochrony Środowiska. Znajdujący się tam dokument zatytułowany Deklaracja Felicjańskiej Komisji Sprawiedliwości zawiera m.in. następujące słowa: „W duchu św. Franciszka i bł. Marii Angeli, naszej Założycielki, My, Siostry Felicjanki, oddajemy się głoszeniu Ewangelii sprawiedliwości i pokoju. Pragniemy (...) przybliżyć Królestwo Boże” oraz „Szanujemy przyrodę we wszystkich jej formach" (http://www.felicjanki.waw.pl/o-zgromadzeniu/komisja-sprawiedliwosci/9-o-zgromadzeniu [23.01.2018]). 
fryzacją i rozwojem Internetu. Szeroko rozumiane media odgrywają ogromnie wpływową rolę. Nasiliło się jednak przemieszczanie się nie tylko ludzkiej myśli i jej różnych wyrazów (słowo pisane, słowo drukowane tradycyjnie, słowo pisane w Internecie, obrazy statyczne, obrazy dynamiczne), obecnie mamy do czynienia $\mathrm{z}$ dokonującym się na nieznaną wcześniej skalę fizycznym przemieszczaniem się ludzi. Jego ocena oraz prognozy na przyszłość oscylują wokół dialogu i pokojowej wymiany a obaw o przyszłość, wrogości, walki. Bynajmniej nie zniknęło wyzwanie, jakim są: ubóstwo, wykluczenia, głód, niedożywienie. Podobnie w przypadku wyzwań związanych z chorobą, życiem osób niepełnosprawnych, obłożnie chorych czy w fazie terminalnej, zmagamy się ze starością, z zapewnieniem godziwych warunków życia osobom w podeszłym wieku. Przy czym niepełnosprawność, choroba, starość dotyczą także otoczenia, zwłaszcza najbliższych danej osoby. Dają też nadal o sobie znać - choć jest to zaskakujące - nierozwiązane problemy związane z młodym pokoleniem, np. jeśli chodzi o możliwość zdobycia wykształcenia, znalezienie pracy, która przynosi dochody na właściwym poziomie oraz satysfakcję.

\section{Misja felicjanek: współpraca z Chrystusem w duchowej odnowie świata w odpowiedzi na powołanie}

W cyberprzestrzeni, stanowiącej obecnie w praktyce jedno z najważniejszych źródeł wiedzy, można znaleźć informację - jej pochodzenie upoważnia, by określić ją mianem autoryzowanej - wskazującą, że misja felicjanek przedstawia się jako współpraca z Chrystusem w duchowej 
odnowie świata w odpowiedzi na powołanie ${ }^{8}$. Ewangelia wg św. Mateusza wskazuje, by uwzględnić w tym wypadku następujące, ściśle ze sobą związane wymiary: nawrócenie-uświęcenie, związek z rzeczywistością, która określana jest mianem królestwa Bożego, oraz udostępnienie-przyjęcie związanego z nimi nauczania. „Odtąd począł Jezus nauczać i mówić: «Nawracajcie się, przybliżyło się królestwo niebieskie»" (Mt 4, 17).

Gdy chodzi o felicjanki, internauta jest w stanie znaleźć następujące przesłanie: „W duchu św. Franciszka i bł. Marii Angeli, naszej Założycielki, My, Siostry Felicjanki, oddajemy się głoszeniu Ewangelii sprawiedliwości i pokoju. Pragniemy

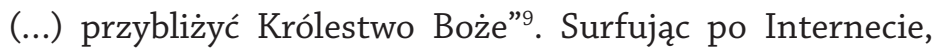
można dowiedzieć się też, że według św. Jana Pawła II współdziałanie Bóg-człowiek jest w przypadku zgromadzenia bardzo ścisłe, a przynajmniej może i powinno takie być. „Podczas długich godzin modlitwy przed Najświętszym Sakramentem nauczyła się, że ona [tzn. założycielka felicjanek] i siostry są wezwane, aby «upodabniały się do śmierci Pana» (Flp 3, 10), tak aby mogły stać się Eucharystią"10. W tak zarysowującym się programie duchowej odnowy

${ }^{8}$ Felician Franciscan Sisters, Congregation of the Sisters of Saint Felix of Cantalice, http://feliciansisters.org (24.01.2018). Zob. M. Winowska, Idź i odnów mój dom! Prawdziwe oblicze Angeli Truszkowskiej, tłum. Z. Wilczkowa, Warszawa 1999, s. 51 i n.

9 Deklaracja Felicjańskiej Komisji Sprawiedliwości, Zgromadzenie Sióstr św. Feliksa z Kantalicjo - Prowincja Matki Bożej Królowej Polski w Warszawie, http://www.felicjanki.waw.pl/o-zgromadzeniu/komi sja-sprawiedliwosci/9-o-zgromadzeniu (23.01.2018).

10 Jan Paweł II, Przesłanie do delegatek 21. Kapituty Generalnej Zgromadzenia Sióstr św. Feliksa z Kantalicjo (16.06.2000), nr 3, http://www.felicjanki.przemysl.pl/index.php?przeslanie,77 (12.08.2018). Zob. B. Dmowska, 
świata mamy do czynienia z trzema ważnymi, połączonymi ze sobą obszarami działania: 1) Bóg powołuje i uzdalnia do udzielenia odpowiedzi, człowiek rozeznaje powołanie i odpowiada na nie; 2) spotkanie, na zasadzie współpracy podmiotów, zaangażowania ze strony Bożej i zaangażowania ze strony powołanego człowieka; 3) duchowa odnowa świata jako obszar czy płaszczyzna, przedmiot, cel tej współpracy.

Zakładając, że Bóg udziela daru powołania i złączonego z nim uzdolnienia człowieka do adekwatnego działania, a człowiek daje w swej wolności odpowiedź, dynamikę, z jaką mamy tu do czynienia, można lepiej zrozumieć, uwzględniając następujące elementy. Abraham, uznawany za figurę osoby zakonnej, a jego powołanie za figurę powołania zakonnego $^{11}$, jak to przedstawia List do Rzymian: uwierzył Bogu ,jako Temu, który ożywia umarłych i to, co nie istnieje, powołuje do istnienia”, a z wiary zrodziły się następnie jego działania ( $\mathrm{Rz}$ 4, 17 wraz z kontekstem). Pierwszy List do Koryntian następująco przedstawia, co się dzieje, gdy Bóg powołuje: „to, co nie jest, wybrał Bóg (...). Przez Niego bowiem jesteście w Chrystusie Jezusie, który stał się dla nas mądrością od Boga i sprawiedliwością, i uświęceniem, i odkupieniem" (1 Kor 1, 28-30). W udzieleniu i podjęciu powołania ma miejsce spotkanie na zasadzie współpracy podmiotów: zaangażowania ze strony Boga i zaangażowania ze strony powołanego człowieka. „My bowiem jesteśmy współpracownikami [gr. synergoi] Boga” (1 Kor 3, 9). Przed powołanym otwierają się takie możliwości, że nasuwa się Aby żyć, trzeba umrzeć. Matka Maria Angela Truszkowska, założycielka Zgromadzenia Sióstr Felicjanek, 1825-1899, Warszawa 1996, s. 5 i n.

${ }^{11}$ D. Barsotti, Abramo, [w:] Dizionario enciclopedico di spiritualità, t. 1, a cura di E. Ancilli i in., Roma 1992, s. 11. 
wniosek, by mówić o pewnej mistyce współdziałania: „za łaską Boga jestem tym, czym jestem, a dana mi łaska Jego nie okazała się daremna; przeciwnie, pracowałem więcej od nich wszystkich, nie ja, co prawda, lecz łaska Boża ze mną" $(1 \text { Kor } 15,10)^{12}$.

Jak to określają same siostry felicjanki, ich powołanie to współpraca z Chrystusem w duchowej odnowie świata. Określenia „odnowa” i „duchowa” zasługują, by zwrócić na nie uwagę. Program i działania zawarte w słowach „odnowa świata" przywołują na myśl dwie koncepcje: 1) fuga mundi, czyli ucieczka od, ze świata; 2) consecratio mundi, czyli życie razem ze światem, w nim, w pewnym sensie dla niego, by przyczynić się do jego konsekracji, uświęcenia. Za tymi określeniami kryje się złożona historia, w tym błędne interpretacje czy też znajdowanie uzasadnienia dla odrzucenia chrześcijańskiego życia zakonnego (jak też chrześcijaństwa jako takiego). Dla podjętego tematu ważne jest, by uwzględnić następujący tok myślenia. Fuga mundi, czyli ucieczka od świata doczesnego, ucieczka z niego, mogła być jednostronnie rozumiana nawet jako swoista zdrada, tchórzostwo, przyznanie się przegranej, wskazanie, że zło jest mocniej$\mathrm{sze}^{13}$. Takiemu podejściu przeczy jednak zaangażowanie felicjanek np. w nauczanie, szkolnictwo, dzieła miłosierdzia. Consecratio mundi, ujmując w skrócie, to właściwe chrześci-

${ }^{12}$ Zob. V. Macca, O życiu mistycznym bł. Marii Angeli Truszkowskiej, tłum. M.P. Lenart, Rzym-Kraków 2011, s. 9 i n.

${ }^{13}$ Zob. L. Bouyer, La spiritualità dei padri (III-VI secolo). Monachesimo antico e Padri. Nuova edizione italiana ampliata e aggiornata a cura di L. Dattrino e P. Tamburrino, Bolonia 1986, s. 32 i n.; F. Sesé, Fuga mundi, [w:] Dizionario enciclopedico di spiritualità, t. 2, a cura di E. Ancilli i in., Roma 1992, s. 1062 i n. 
jaństwu, w tym życiu zakonnemu, zaangażowanie, by świat doczesny czynić lepszym w ramach aktywnego podjęcia daru stworzenia i odkupienia ${ }^{14}$. Duchowa odnowa świata to właśnie takie consecratio mundi. Nie chodzi więc np. o powrót do szczęśliwej przeszłości, w sensie biblijnego „nowego stworzenia" (np. 2 Kor 5, 17), chodzi o odnowę i rozwój, przezwyciężenie zła i osiągnięcie pełni rozwoju. Zatem nie o odcieleśnienie czy odmaterializowanie, ale o uduchowienie w sensie otwarcia się na Boga, o bycie coraz bardziej przez Niego ożywianym ${ }^{15}$. Takie właśnie zaangażowanie, w duchu np. Mt 25, 31-46, jest traktowane jako normalna droga do najważniejszego celu, jakim jest Bóg i zjednoczenie z Nim nie tylko w doczesności, ale ostatecznie w pełni w wieczności.

W takim razie odnowa duchowa świata pozostaje w związku ze świętością właściwa Bogu i przez Niego udzielana. Bóg nie jest tu w defensywie, nie wycofuje się, nie izoluje. Mamy natomiast do czynienia z procesem jej udzielania, skutecznej przemiany na lepsze, rozkwitu. Bardzo pouczająca pod tym względem jest słynna scena powołania proroka Izajasza (Iz 6, 1-8). Wiele mówią dwa następujące teksty ze Starego i Nowego Testamentu: „Ponieważ Ja jestem Pan, Bóg wasz - uświęćcie się! Bądźcie świętymi, ponieważ Ja jestem święty! (...) Bo Ja jestem Pan, który wyprowadził was z ziemi egipskiej, abym był waszym Bogiem. Bądźcie więc świętymi, bo Ja jestem święty!" (Kpł 11, 44-45, zob. 19, 2n;

${ }^{14}$ Zob. M. Belda Plans, Animazione cristiana del mondo, [w:] Dizionario enciclopedico di spiritualità, t. 1, dz. cyt., s. 146 i n.

${ }_{15}$ Zob. Y.M.-J. CongAR, Wierzę w Ducha Świętego, t. 1: Duch Święty $w$ „ekonomii”. Objawienie i doświadczenie Ducha, tłum. A. Paygert, Warszawa 1995, s. 38. 
20, 7); „(...) w całym postępowaniu stańcie się wy również świętymi na wzór Świętego, który was powołał, gdyż jest napisane: Świętymi bądźcie, bo Ja jestem święty" (1 P 1, 15-16). Ten proces można też określić jako obdarzenie chwałą czy usynowienie i z punktu widzenia człowieka nie jest on pozbawiony wyzwań. „Sądzę bowiem, że cierpień teraźniejszych nie można stawiać na równi z chwałą, która ma się w nas objawić. Bo stworzenie z upragnieniem oczekuje objawienia się synów Bożych. Stworzenie bowiem zostało poddane marności - nie z własnej chęci, ale ze względu na Tego, który je poddał - w nadziei, że również i ono zostanie wyzwolone z niewoli zepsucia, by uczestniczyć w wolności i chwale dzieci Bożych" (Rz 8, 18-21).

Tak rozumiana odnowa duchowa świata nie oznacza, by chrześcijanie dbali jedynie o siebie czy by zaniedbana została troska o zbawienie wieczne. Ważne jest nauczanie Soboru Watykańskiego II, a szczególnie następujące dwa teksty:

Odnosi się to nie tylko do chrześcijan, lecz także do wszystkich ludzi dobrej woli, w których sercu w niewidzialny sposób działa łaska. Skoro bowiem Chrystus umarł za wszystkich i skoro ostateczne powołanie człowieka jest $\mathrm{w}$ istocie jedno, mianowicie Boskie, powinniśmy utrzymywać, że Duch Święty wszystkim daje możliwość uczestniczenia w tym misterium paschalnym w tylko Bogu znany sposób ${ }^{16}$.

${ }^{16}$ Sobór Watykański II, konst. duszpasterska o Kościele w świecie współczesnym Gaudium et spes (7.12.1965), nr 22, [w:] Sobór Watykański II, Konstytucje, dekrety, deklaracje. Tekst polski. Nowe tłumaczenie, Poznań 2002, s. 542. 
(...) całe to stworzenie, które Bóg stworzył ze względu na człowieka, zostanie wyzwolone $\mathrm{z}$ niewoli zepsucia. (...) Kiedy bowiem w Duchu Pańskim i według Jego polecenia rozkrzewimy na ziemi ludzką godność, braterską wspólnotę i wolność, tzn. wszystkie te dobre owoce natury i naszego wysiłku, to znów je potem znajdziemy, oczyszczone już jednak z wszelkiej nieczystości, rozświetlone i przemienione, gdy Chrystus przekaże Ojcu wieczne i powszechne królestwo: „Królestwo prawdy i życia, królestwo świętości i łaski, królestwo sprawiedliwości, miłości i pokoju". Na tej ziemi królestwo jest już obecne w misterium; kiedy zaś przyjdzie Pan, osiągnie ono pełnię ${ }^{17}$.

Jeśli słuszna jest opinia, że współdziałając z Bogiem, chrześcijanie przyczyniają się do przyspieszenia paruzji i nastania pełni zbawienia ${ }^{18}$, to duchowa odnowa świata wpisuje się w taką właśnie dynamikę. I dotyczy to, jak już w 1973 roku stwierdził papież Paweł VI, także najnowszych zdobyczy technologicznych: „W stopniu, w jakim środki społecznego przekazu afirmują i promują wartości duchowe ludzkości stale zaangażowanej w poszukiwania, przyczyniają się one do przygotowania dnia nowego stworzenia, kiedy to ojcostwo Boga będzie powszechnie rozpoznane i będą królować braterstwo, sprawiedliwość i pokój”19.

17 Sobór Watykański II, konst. duszpasterska o Kościele w świecie współczesnym Gaudium et spes, nr 39.

18 Tak uważa A. Jankowski, „Spiritus consummator” czyli ostateczne zadanie Ducha Świętego, [w:] Napełnieni Duchem Świętym. Praca zbiorowa, Poznań 1982, s. 197.

${ }^{19}$ Paweł VI, akapit 9, messaggio per la VII Giornata Mondiale delle Comunicazioni Sociali Le comunicazioni sociali e l'affermazione e promozione dei valori spirituali (1.05.1973), http://w2.vatican.va/content/paul-vi/ it/messages/communications/documents/hf_p-vi_mes_19730501_viicom-day.htm (20.07.2016). 


\section{Świadectwo życia: otwartość na potrzebujących pomocy}

„Chrześcijańskiego świadectwa nie daje się przez bombardowanie treściami religijnymi, lecz przez chęć dawania siebie innym "przez gotowość do cierpliwego i naznaczonego szacunkiem zainteresowania się ich pytaniami i wątpliwościami na drodze poszukiwania prawdy i sensu ludzkiego istnienia» (Benedykt XVI, Orędzie na XLVII Światowy Dzień Środków Społecznego Przekazu 2013)"20. W ten sposób papież Franciszek, cytując papieża Benedykta XVI, przedstawia samą istotę bycia chrześcijaninem, wypełniania mandatu misyjnego powierzonego chrześcijanom przez Chrystusa. „Idźcie więc i nauczajcie wszystkie narody, udzielając im chrztu w imię Ojca i Syna, i Ducha Świętego. Uczcie je zachowywać wszystko, co wam przykazałem. A oto Ja jestem z wami przez wszystkie dni, aż do skończenia świata" (Mt $28,19-20)$. Współpraca w duchowej odnowie świata to m.in. różne formy apostolatu, w tym takie, które wiążą się $\mathrm{z}$ dziełami miłosierdzia, z zaradzaniem potrzebom również doczesnym ${ }^{21}$.

20 Franciszek, messaggio per la XLVIII Giornata Mondiale delle Comunicazioni Sociali Comunicazione al servizio di un'autentica cultura dell'incontro (24.01.2014), akapit 9, http://w2.vatican.va/content/ francesco/it/messages/communications/documents/papa-francesco_20140124_messaggio-comunicazioni-sociali.html (24.01.2014).

${ }^{21}$ Zob. Benedykt XVI, enc. do biskupów, prezbiterów i diakonów, do osób konsekrowanych i wszystkich wiernych świeckich o miłości chrześcijańskiej Deus caritas est (25.12.2005), nr 24 i n., http://w2.vatican.va/content/benedict-xvi/pl/encyclicals/documents/hf_ben-xvi_ enc_20051225_deus-caritas-est.html (28.01.2006). 
Najnowsze osiągnięcia technologiczne obecnie to chociażby Internet. $\mathrm{Z}$ udostępnionych za jego pomocą danych odbiorca może się dowiedzieć, że na apostolat sióstr felicjanek składają się takie wymiary jak: działalność wychowawcza, działalność opiekuńcza, dzieła miłosierdzia, praca w parafiach oraz praca poza granicami Polski ${ }^{22}$. Internauta otrzymuje też do dyspozycji bardziej szczegółowe informacje, dzięki którym może lepiej ocenić felicjanki czy znaleźć inspirację. I tak istotę apostolatu ukazują następujące stwierdzenia: „Naszym podstawowym apostolatem w Kościele, jako osób konsekrowanych, jest świadectwo życia”; „Staramy się być otwarte na różnorodne potrzeby ludu Bożego, szczególnie wobec ubogich i potrzebujących”; „Jedynie żyjąc wiarą, nadzieją i miłością, możemy nieść Chrystusa tym, których spotykamy w naszym apostolacie”; „W naszych wspólnych apostolatach w Kościele służymy ludowi Bożemu, oddajemy się służbie ewangelizacji”23. Lakoniczność jest tu cenna, ponieważ współczesny człowiek boryka się ze skierowanym ku sobie nadmiarem bodźców, wiadomości etc. Osoba zaznajomiona $\mathrm{z}$ teologią może powyższe stwierdzenia uznać za klasyczne, jeśli chodzi o prezentację charyzmatu zakonnego.

22 Zgromadzenie Sióstr św. Feliksa z Kantalicjo - Prowincja Matki Bożej Królowej Polski w Warszawie, http://www.felicjanki.waw.pl (31.01. 2018). Zob. Ł. Hajduk, Pedagogia felicjanek (Zgromadzenia Sióstr Świętego Feliksa z Kantalicjo), [w:] Pedagogie katolickich zgromadzeń zakonnych, t. 3: Historia i wspótczesność, red. J. Kostkiewicz, Kraków 2013, s. 375 i n.; R. Bogusz, Klasztor SS. Felicjanek w Krakowie ośrodkiem katechumenatu w latach 1873-1914, „Krakowski Rocznik Archiwalny” 9 (2003), nr 12332135, s. 149 i n.

${ }^{23}$ Zgromadzenie Sióstr św. Feliksa z Kantalicjo - Prowincja Matki Bożej Królowej Polski w Warszawie, http://www.felicjanki.waw.pl/apostolstwo (31.01.2018). 
Podobnie można podejść na kolejnych informacji. W przypadku zaliczanej do apostolatu działalności wychowawczej jest to np. prowadzenie w duchu felicjańskim szkół, przedszkoli, katechizacja, spotkania absolwentów. Na działalność opiekuńczą składa się funkcjonowanie ośrodków opieki całodobowej i pobytu dziennego. Zaangażowanie charytatywne to np. prowadzenie ośrodka socjoterapeutycznego i jadłodajni. Aktywność określona jako religijna to ewangelizacja i katechizacja oraz włączenie się w pracę takich struktur kościelnych jak diecezje i parafie ${ }^{24}$. Mamy więc do czynienia z podejściem, które można uznać za klasyczne i charakterystyczne - w jak najbardziej pozytywnym znaczeniu - dla chrześcijańskiej duchowości zakonnej, a zwłaszcza dla chryzmatu felicjańskiego. To wierność i odczytywanie współczesnych potrzeb. Widać też, że potrzeby, którym siostry starają się zaradzić, cechuje pewna trwałość: towarzyszyły one już powstaniu zgromadzenia, stały się wręcz przyczyną jego utworzenia i rozwoju. „(..) ubogich zawsze macie u siebie" - mówi Chrystus w Ewangelii św. Jana (J 12, 8). Współczesność nie stanowi tu wyjątku: do niej także odnoszą się przytoczone słowa. Przynosi ona nawet nowe obszary, w których ludzie potrzebują pomocy. „Wśród tych dróg [czyli tam, gdzie ludzie żyją, gdzie można ich spotkać, dokąd wychodzi czy ma wychodzić Kościół] są również drogi cyfrowe, pełne ludzi, często zranionych: mężczyzn i kobiet, którzy szukają zbawienia [wł. cercano una salvezza] lub nadziei"25.

${ }^{24}$ Zgromadzenie Sióstr św. Feliksa z Kantalicjo - Prowincja Matki Bożej Królowej Polski w Warszawie, http://www.felicjanki.waw.pl/apostolstwo (31.01.2018).

${ }^{25}$ Franciszek, messaggio la XLVIII Giornata Mondiale delle Comunicazioni Sociali Comunicazione al servizio di un'autentica cultura dell'incontro 
Włoskie salvezza posiada dwa zasadnicze znaczenia: 1) ratunek, 2) zbawienie (to ostatnie w znaczeniu teologicznym). Także tekst hiszpański - dla papieża Franciszka język hiszpański to język ojczysty, a włoski to znany mu język rodziny, z której się wywodzi, oraz język jego diecezji rzymskiej ${ }^{26}$ skłania, by nie wykluczać, ale łączyć ratunek i zbawienie, to jest znaczenie teologiczne, związane z duchowością, ze znaczeniem odnoszącym się szerzej, do uwarunkowań ludzkiej egzystencji: „buscan una salvación”27. Obecność rodzajnika nieokreślonego una tak w tekście włoskim, jak i hiszpańskim też prowadzi w tym kierunku.

Nowoczesność daje też nowe możliwości, by wywiązać się jak najlepiej powierzonego chrześcijanom przykazania miłości. Już wlatach 60. i 70. ubiegłego stulecia papież Paweł VI, oceniając rozwijający się coraz szybciej i nieraz zaskakująco przekaz medialny, stwierdził: „W stopniu, w jakim środki społecznego przekazu afirmują i promują wartości duchowe ludzkości stale zaangażowanej w poszukiwania, przyczyniają się one do przygotowania dnia nowego stworzenia, kiedy to ojcostwo Boga będzie powszechnie rozpo-

(24.01.2014), za: http://w2.vatican.va/content/francesco/pl/messages/ communications/documents/papa-francesco_20140124_messaggio-comunicazioni-sociali.html, dostęp 5.10.2014, akapit 8 .

${ }^{26}$ Zob. Franciszek, Benedizione apostolica Urbi et Orbi. Primo Saluto, http://w2.vatican.va/content/francesco/it/homilies/2013/documents/papa-francesco_20130319_omelia-inizio-pontificato.html, dostęp: 18.07.2018, akapit 1.

${ }^{27}$ Franciszek, Mensaje para la XLVIII Jornada Mundial de las Comunicaciones Sociales Comunicación al servicio de una auténtica cultura del encuentro (24.01.2014), http://w2.vatican.va/content/francesco/ es/messages/communications/documents/papa-francesco_20140124_ messaggio-comunicazioni-sociali.html, dostęp: 18.07.2018. 
znane i będą królować braterstwo, sprawiedliwość i pokój”28. W tym samym kierunku prowadzi papież Jan Paweł II: „Nie lękajcie się nowych technologii! Są one «wśród niezwykłych wynalazków» - inter mirifica - które Bóg dał nam do dyspozycji" ${ }^{29}$. Słowa te zawierają ważne wskazania dla oceny oraz istotne inspiracje w kwestii chrześcijańskiej obecności w świecie nowych technologii i możliwości związanych z komunikacją; strony internetowe też się tu plasują.

\section{Modlitwa: obecność i żywotność}

Modlitwa jest bardzo dawną czynnością. Jest dużo starsza niż chrześcijaństwo, znacznie starsza niż porządek kształtowany przez prawo mojżeszowe.

Gdy po niejakim czasie Kain składał dla Pana w ofierze płody roli, zaś Abel składał również pierwociny ze swej trzody i z ich tłuszczu, Pan wejrzał na Abla i na jego ofiarę; na Kaina zaś i na jego ofiarę nie chciał patrzeć. Smuciło to Kaina bardzo i chodził z ponurą twarzą. Pan zapytał Kaina: „Dlaczego jesteś smutny i dlaczego twarz twoja jest ponura? Przecież gdybyś postępował dobrze, miałbyś twarz pogodną; jeżeli zaś nie będziesz dobrze postępował, grzech leży u wrót i czyha na ciebie, a przecież ty masz nad nim panować" (Rdz 4, 3-7).

${ }^{28}$ Paweł VI, messaggio per la VII Giornata Mondiale delle Comunicazioni Sociali Le comunicazioni sociali e l'affermazione e promozione dei valori spirituali (1.05.1973), akapit 9.

29 Jan Paweł II, lettera apostolica ai responsabili delle comunicazioni sociali Il rapido sviluppo (24.01.2005), nr 14, http://w2.vatican. va/content/john-paul-ii/it/apost_letters/2005/documents/hf_jp-ii_ apl_20050124_il-rapido-sviluppo.html (20.08.2015). 
Przytoczony tekst, należący do biblijnego przekazu dotyczącego początków świata, wskazuje m.in. na następujące sprawy. Modlitwa pozostaje w związku ze zwycięstwem nad złem i grzechem, z tym, że człowiek staje się, czy przynajmniej ma taką szansę, lepszym. Modlitwa nie jest monologiem, człowiek nie jest skazany na bycie odciętym od Boga, na brak komunikacji z Nim dającej szczęście. Natomiast człowiekowi może być potrzebna pomoc, by z takich możliwości skorzystać, np. uświadomienie mu warunków, które należy spełnić.

Sieci społecznościowe mogą być nie tylko narzędziem ewangelizacji, ale również czynnikiem ludzkiego rozwoju. (...) Na przykład w niektórych sytuacjach geograficznych i kulturowych, gdzie chrześcijanie czują się izolowani, mogą one umacniać poczucie ich rzeczywistej jedności z powszechną wspólnotą wierzących. Sieci ułatwiają dzielenie się bogactwem duchowym i liturgicznym, sprawiając, że ludzie mogą modlić się z żywym poczuciem bliskości tych, którzy wyznają tę samą wiarę. Prawdziwe i interaktywne zaangażowanie w pytania i wątpliwości tych, którzy są dalecy od wiary, powinno nam uzmysłowić potrzebę podtrzymywania przez modlitwę i refleksję naszej wiary w obecność Boga, jak i naszej aktywnej dobroczynności ${ }^{30}$.

Do podstawowych zadań osoby konsekrowanej należy pokazywanie innym, jak się modlić, bycie nauczycielem modlitwy i orędownikiem przed Bogiem ${ }^{31}$. Dzisiaj do klasztoru

${ }^{30}$ Benedykt XVI, messaggio per la XLVII Giornata Mondiale delle Comunicazioni Sociali Reti Sociali: porte di verità e di fede; nuovi spazi di evangelizzazione (24.01.2013), akapit 9.

${ }^{31}$ Zob. Jan Paweł II, posynodalna adhort. apost. do biskupów i duchowieństwa, do zakonów i zgromadzeń zakonnych do stowarzyszeń 
ludzie „pukają” - może (oceniając po ludzku) nieraz zupełnie przypadkowo - także we wskazany poniżej sposób. Przez sieć i związane $z$ nią portale wspólnotom zakonnym została powierzona do owocnego wykorzystania jeszcze jedna furta, rozmównica czy przestrzeń modlitwy, by modląc się, być z innymi czy też uczyć innych modlić się. Zadość czyniąc klauzurze klasztornej, jest to otwarcie się i nawet wyjście ku potrzebującym pomocy ${ }^{32}$. Papież Franciszek wywodzi się z zakonu jezuitów. W maju 2016 roku pisał następująco na portalu Stolicy Apostolskiej: „Tobie, który z wielkiej wspólnoty cyfrowej prosisz mnie o błogosławieństwo i modlitwę, chcę powiedzieć: ty będziesz drogocennym darem w mojej modlitwie do Ojca. A ty nigdy nie zapomnij modlić się za mnie i za moje bycie sługą Ewangelii Miłosierdzia" ${ }^{\text {"3 }}$.

Czego o modlitwie może dowiedzieć się od felicjanek przybysz, który zawędruje na ich strony internetowe? Przede wszystkim temat modlitwy nie został tam przeoczony, a to jest sprawa pozytywnie podstawowa. Modlitwa została przedstawiona jako rzeczywistość bardzo ważna, centralna, o kluczowym znaczeniu. Przytoczono następujące słowa matki Marii Angeli Truszkowskiej, założycielki

życia apostolskiego do instytutów świeckich oraz do wszystkich wiernych o życiu konsekrowanym i jego misji w Kościele i w świecie Vita consecrata (25.03.1996), nr 39, 95, https://w2.vatican.va/content/john-paul-ii/pl/ apost_exhortations/documents/hf_jp-ii_exh_25031996_vita-consecrata.html (25.07.2018).

32 Zob. Franciszek, messaggio per la XLVIII Giornata Mondiale delle Comunicazioni Sociali Comunicazione al servizio di un'autentica cultura dell'incontro (24.01.2014), akapit 8.

${ }^{33}$ Franciszek, A te, che dalla grande comunità digitale, http://w2.vatican.va/content/vatican/it.html (9.05.2016). 
felicjanek: "Całym naszym bogactwem jest modlitwa" Modlitwa jest związana z nadzieją, ona jest bardzo cenną pomocą. „Kto się modli, wszystko otrzymuje” ${ }^{35}$. Modlitwa to jakiś ubogi monolog, lecz spotkanie bogate uczestnikami i treściami, ściśle związane z życiem danej osoby i zarazem z misterium Kościoła, w tym normatywnych dla niego ksiąg, łączności między niebem i doczesnością. „Modlić się to mówić do Boga, zwierzać się ze wszystkich radości i niepokojów, powierzać Mu siebie. (...) Modlę się słowami Pisma Świętego, słowami, które wypowiada sam Chrystus Pan i Święci Pańscy. Modlę się, uczestnicząc w modlitwie wspólnoty Kościoła" ${ }^{36}$. Wzmianka o Biblii inspiruje, by pójść w tym kierunku. Tym bardziej że siostry felicjanki udostępniają w formie linków w Internecie tekst Pisma Świętego ${ }^{37}$ i liturgię godzin ${ }^{38}$, a ta ostatnia przecież składa się z odpo-

${ }^{34}$ Zgromadzenie Sióstr św. Feliksa z Kantalicjo - Prowincja Matki Bożej Częstochowskiej w Przemyślu, http://www.felicjanki.przemysl.pl/ index.php?modlitwa,37 (8.02.2018). Zob. P. Wieczorek, Bł. siostra Maria Angela Truszkowska, Kraków 2002, s. 15 i n.

35 Zgromadzenie Sióstr św. Feliksa z Kantalicjo - Prowincja Matki Bożej Częstochowskiej w Przemyślu, http://www.felicjanki.przemysl.pl/ index.php?modlitwa,37 (8.02.2018). Zob. L. Rotter, The cult of saints in religious orders. The example of the Congregation of the Felician Sisters, „Folia Historica Cracoviensia" 13 (2007), s. 109 i n.

36 Zgromadzenie Sióstr św. Feliksa z Kantalicjo - Prowincja Matki Bożej Częstochowskiej w Przemyślu, http://www.felicjanki.przemysl.pl/ index.php?modlitwa,37 (8.02.2018).

${ }^{37}$ Zgromadzenie Sióstr św. Feliksa z Kantalicjo - Prowincja krakowska Niepokalanego Serca Maryi, http://www.felicjanki.pl/o-nas (26.07. 2018).

38 Zgromadzenie Sióstr św. Feliksa z Kantalicjo - Prowincja krakowska Niepokalanego Serca Maryi, http://www.felicjanki.pl/o-nas/ (26.07. 2018). 
wiednio dobranych tekstów biblijnych, które wyznaczają właściwy tej modlitwie bieg oraz oddziaływanie.

Na nauczanie Soboru Watykańskiego II składa się następujące wyjaśnienie, co dzieje się, kiedy człowiek czyta Pismo Święte:

Kościół zawsze otaczał czcią Boże Pisma, podobnie jak i samo Ciało Pańskie. Zwłaszcza w liturgii świętej bierze ciągle chleb życia ze stołu Bożego słowa i Ciała Chrystusowego i podaje wierzącym. Pisma te w połączeniu ze świętą Tradycją uważał i uważa zawsze za najwyższą regułę swej wiary, ponieważ natchnione przez Boga i spisane raz na zawsze, niezmiennie przekazują Boże słowo i sprawiają, że w wypowiedziach Apostołów i proroków rozbrzmiewa głos Ducha Świętego. Tak całe przepowiadanie kościelne, jak i sama religia chrześcijańska, musi się karmić Pismem Świętym i nim się kierować. W świętych bowiem księgach Ojciec, który jest w niebie, $\mathrm{z}$ wielką miłością wychodzi swoim dzieciom naprzeciw i rozmawia z nimi. Tak wielka zaś w słowie Bożym zawiera się moc i potęga, że staje się ono dla Kościoła podstawą i siłą żywotną, a dla dzieci Kościoła umocnieniem wiary, pokarmem duszy, czystym i trwałym źródłem życia duchowego. Toteż bardzo słusznie do Pisma Świętego odnoszą się słowa: „Żywe jest słowo Boże i skuteczne" (Hbr 4, 12), „władne zbudować i dać dziedzictwo ze wszystkimi świętymi" (Dz 20, 32; por. 1 Tes 2, 13) ${ }^{39}$.

Jak w świetle przytoczonego nauczania Kościoła odpowiedzieć na następujące pytania: kto do człowieka mówi, gdy czyta on Pismo Święte dzięki portalowi internetowe-

39 Sobór Watykański II, konst. dogmatyczna o Objawieniu Bożym Dei Verbum (18.11.1965), nr 21, [w:] Sobór Watykański II, Konstytucje, dekrety, deklaracje..., dz. cyt., s. 359 i n. 
mu? Kto wtedy do tego człowieka „z wielką miłością wychodzi (...) naprzeciw i rozmawia"? Czy umożliwienie takiego błogosławionego spotkania przez portal internetowy nie jest bardzo ważnym wkładem w duchową odnowę świata, ludzi, w otwieranie drzwi szukającym, może i po omacku, ratunku, zbawienia, nadziei? Czy nie jest to obecnie bardzo ważny nurt zaangażowania apostolskiego i dialogu, jakim jest modlitwa? Internet przedstawia się jako Boże narzędzie i miejsce miłości, łaski, spotkania, zjednoczenia także w związku z modlitwą. Ona sama zawsze jest darem Ducha Świętego (1 Kor 12, 3).

W związku z internetową liturgią godzin trzeba i warto uwzględnić bogate, inspirujące, głębokie nauczanie Kościoła na temat tzw. modlitwy brewiarzowej. Sobór Watykański II następująco wprowadza w jej wzniosłe i zarazem udostępnione potrzebującym zbawienia misterium: „Jezus Chrystus, Najwyższy Kapłan Nowego i Wiecznego Testamentu, (...) wniósł w to ziemskie wygnanie ów hymn, który w niebiańskich przybytkach rozbrzmiewa po wszystkie wieki. Całą społeczność ludzi łączy On ze sobą i przez ten śpiew Bożej pieśni pochwalnej ze sobą ją zespala”. Zaraz potem Sobór dodaje: „To kapłańskie zadanie [Chrystus] wykonuje nadal przez swój Kościół, który nieustannie wielbi Pana i wstawia się za zbawienie całego świata nie tylko przez celebrowanie Eucharystii, lecz także innymi sposobami, zwłaszcza przez modlitwę godzin"40. W 2010 roku pa-

40 Sobór Watykański II, konst. o liturgii świętej Sacrosanctum Concilium (4.12.1963), nr 83, [w:] Sobór Watykański II, Konstytucje, dekrety, deklaracje..., dz. cyt., s. 67. Zob. też Paweł VI, konst. apostolska wprowadzająća w życie Liturgię Godzin uchwaloną dekretem Drugiego Soboru Watykańskiego (1.11.1970), nr 8, [w:] Liturgia Godzin. Codzienna 
pież Benedykt XVI zwracał uwagę: „świat cyfrowy, oddając do dyspozycji środki umożliwiające niemal nieskończoną zdolność wyrazu, otwiera wielkie perspektywy i aktualizacje dla Pawłowego wezwania: «Biada mi, gdybym nie głosił Ewangelii!» (1 Kor 9, 16). Toteż wraz z ich rozpowszechnieniem odpowiedzialność za głoszenie nie tylko wzrasta, ale staje się coraz pilniejsza i wymaga bardziej uzasadnionego i skuteczniejszego zaangażowania" ${ }^{\text {"1 }}$. Głoszenie Ewangelii stanowi jedno z modleniem się, z uczeniem, jak się modlić (np. Mt 28, 18-20; Łk 11, 1-4). Nowy, charakterystyczny dla współczesności, cyfrowy wymiar spotkania z Bogiem i Jego światem nie oznacza bynajmniej, jak na to wskazał papież Benedykt XVI, jakoby miało nastąpić zamknięcie, zgubne wyobcowanie w świecie wirtualnym.

Istnieją sieci społecznościowe, które w świecie cyfrowym stwarzają współczesnemu człowiekowi okazje do modlitwy, medytacji lub dzielenia się Słowem Bożym. Mogą one jednak otworzyć także podwoje na inne wymiary wiary. Wiele osób odkrywa bowiem właśnie dzięki kontaktowi, który początkowo miał miejsce online, znaczenie kontaktu bezpośredniego, doświadczenia wspólnoty, a nawet pielgrzymki - będących nieustannie ważnymi elementami na drodze wiary. Szukając sposobów uobecnienia Ewangelii w środowisku cyfrowym, możemy zaprosić ludzi do prze-

modlitwa ludu Bożego, t. 1: Okres adwentu. Okres Narodzenia Pańskiego, Poznań 1982, s. 20.

${ }^{41}$ Benedykt XVI, messaggio per la XLIV Giornata Mondiale delle Comunicazioni Sociali Il sacerdote e la pastorale nel mondo digitale: i nuovi media al servizio della Parola (24.01.2010), akapit 3, http://w2.vatican. $\mathrm{va} /$ content/benedict-xvi/it/messages/communications/documents/ hf_ben-xvi_mes_20100124_44th-world-communications-day.html (1.03.2015). 
żywania spotkań modlitewnych lub celebracji liturgicznych w konkretnych miejscach, takich jak kościoły czy kaplice.

Zaraz potem papież dodaje: „Nie powinno brakować nam konsekwencji czy spójności w wyrażaniu naszej wiary i świadectwa Ewangelii w rzeczywistości, w której przychodzi nam żyć - fizycznej czy cyfrowej. Kiedy jesteśmy w jakikolwiek sposób obecni dla innych, jesteśmy wezwani, by umożliwić poznanie miłości Bożej aż po krańce ziemi”42.

Epoka Internetu składa się na doczesność, a dokładniej tę jej część, która zaczęła się wraz z nastaniem pełni czasu, wraz z wejściem w jej złożone, nieraz bardzo trudne i dramatyczne realia posłanych przez Ojca Chrystusa i Ducha Świętego. Epoka Internetu składa się więc na czas misji Kościoła (zob. Ga 1, 1-2; 4, 4-6). Jest to więc także czas zaangażowania się zgromadzeń zakonnych.

Przedstawione informacje nie wyczerpują wskazanego w tytule tematu. Należałoby napomknąć chociażby także o fenomenie tak zwanych skrzynek intencji modlitewnych $^{43}$. Pokazuje to natomiast, w jaki sposób charyzmat zgromadzenia założonego w drugiej połowie XIX wieku jest nadal żywy i rozwija się. Misja sióstr felicjanek obecnie jest

${ }^{42}$ Benedykt XVI, messaggio per la XLVII Giornata Mondiale delle Comunicazioni Sociali Reti Sociali: porte di verità e di fede; nuovi spazi di evangelizzazione (24.01.2013), akapit 10.

${ }^{43}$ Zob. np. Zgromadzenie Sióstr św. Feliksa z Kantalicjo - Prowincja Matki Bożej Częstochowskiej w Przemyślu, http://felicjanki.przemysl.pl/ intencje/kgcall.php?engine=addkg.php (1.02.2018). 
kontynuowana w warunkach znacznie zmienionych. Na tę kontynuację składa się także - co stanowi istotny wymiar wierności misji - dostrzeganie nowych okoliczności czy zadań i podejmowanie ich. W tym kontekście trzeba wskazać na Internet, na obecność w cyberprzestrzeni jako na wychodzenie na spotkanie innym, nieraz potrzebującym pomocy, bycie do ich dyspozycji, np. przez wskazania i przez zaproszenie do modlitwy. 